\title{
The American Association for Thoracic Surgery Second Robert E. Gross Research Scholarship, 2003-2005
}

\author{
STIPEND \$50,000 PER YEAR
}

$T^{\text {he }}$ he American Association for Thoracic Surgery announces the AATS Second Robert E. Gross Research Scholarship to provide an opportunity for research, training, and experience for a North American surgeon committed to pursuing an academic career in cardiothoracic surgery. The scholarship will be funded by the Association and administered by the Graham Education and Research Foundation.

The research program must be undertaken within the first three years after completion of an approved cardiothoracic residency. Applications for the scholarship may be submitted during the candidate's final year of cardiothoracic residency or during his or her first two years in an academic position. The duration of the scholarship is to be two years.

The yearly stipend shall be $\$ 50,000$ paid to the host institution. In addition, a grant of $\$ 5,000$ per year shall be made for support of research supplies, travel, and other legitimate academic expenses of the scholar. Applications for the scholarship are available from the Secretary of The American Association for Thoracic Surgery. The application will consist of three components:

1. The candidate must submit a proposal for the research to be undertaken and a statement of career plans and how the research activity will relate to the candidate's academic career.

2. The Director of the laboratory in the institution at which the research will be performed shall submit an endorsement of the proposal and indicate the facilities and degree of support available for the candidate's research.

3. The Chairman of the candidate's department shall submit his or her endorsement of the proposal and indicate the willingness of the institution to provide an academic appointment for the candidate upon completion of the scholarship.

The application and its three components shall be submitted to the Secretary of The American Association for Thoracic Surgery by July 1, 2002. Announcement of the award will be made by the President of The American Association for Thoracic Surgery by December 15, 2002. The Scholarship will begin July 1, 2003. Following completion of the two-year program the scholar shall submit a written report of his/her research activities to the membership of the Association. In May 2005 the Scholar shall present a five-minute report of his/her experience at the Plenary Session of the AATS annual meeting.
Applications for the scholarship are available from:

Tirone E. David, MD, Secretary

The American Association for Thoracic Surgery

Thirteen Elm Street

Manchester, MA 01944-1314

978-526-8330: fax 978-526-4018

Applications may be downloaded from the AATS Web site at: http://www.aats.org/doc/4939.

\section{Announcement of 2002 Annual Meeting}

$\mathrm{T}$

The Eighty-second Annual Meeting of The American Association for Thoracic Surgery will be held May 5-8, 2002, in Washington, DC, at the Washington Convention Center. The meeting of the Association is open to all physicians. House Officers and Fellows will be admitted without payment of a registration fee upon presentation of a letter from their Chief of Service either during pre-registration or at the time of registration. Nonmember physicians will be required to pay a $\$ 250$ registration fee. Members, nonmember physicians, and invited speakers will have the privilege of discussing papers.

\section{Requests for preregistration forms and hotel reservations}

Information on the 2002 Annual Meeting, including registration, hotel accommodations, and the social program, is available as of January of 2002. Requests should be forwarded directly to:

American Association for Thoracic Surgery

Thirteen Elm Street

Manchester, MA 01944

(978) 526-8330; fax (978) 526-7521

e-mail: aats@prri.com

Registration and hotel information will be available on our Web site at aats.org. 